\title{
A FUZZY APPLICATION OF X-R CONTROL CHARTS OF AN ALUMINUM PRODUCTION PLANT USING FUZZY TRIANGULAR NUMBERS
}

\author{
Volkan ARSLAN*, General Directorate of Minerals Research and Exploration, Turkey, volkanarslan76@hotmail.com \\ (https://orcid.org/0000-0002-5594-1495)
}

Received: 22.04.2020, Accepted: 03.09.2020

*Corresponding author

Research Article

DOI: $10.22531 /$ muglajsci.725550

\begin{abstract}
In this study, fuzzy mean and range control charts were used to follow the feeding material and concentrate production line of Eti Aluminum Co. Fuzzy control charts were collected from the factory over a period of time and compared to Shewhart control charts used by the factory. The results showed that fuzzy control charts detected errors in the production process more accurately than Shewhart control charts. This method has increased quality and efficiency. Process capability indices (PCIs) provide numerical measures as to whether a process has confirmed the defined capability prerequisite. These were used to measure the process's ability to decide how well it meets specification limits (SLs). PCIs have been implemented by companies to evaluate quality and efficiency performance. Fuzzy process capability analysis using $X-R$ control charts gave more accurate results.

Keywords: Statistical Process Control, Fuzzy Control Chart, Process Capability Indices, Aluminum

\section{ALÜMINNYUM ÜRETIM TESISINIIN ÜÇGEN BULANIK SAYILAR KULLANILARAK X-R KONTROL ŞEMALARININ BULANIK MANTIK UYGULAMASI}

\section{Özet}

Bu çalışmada, Eti Alüminyum Şirketinin besleme malı ve konsantre üretim sürecini izlemek için bulanık ortalama ve aralık kontrol grafikleri kullanılmıştır. Bulanık kontrol çizelgeleri, belirli bir süre aralığında fabrikadan veri toplanmış ve fabrika tarafindan kullanılan Shewhart kontrol çizelgeleri ile karşılaştırılmıştır. Sonuçlar, bulanık kontrol grafiklerinin Shewhart kontrol grafiklerine göre üretim sürecindeki hataları daha doğru bir şekilde tespit ettiği görülmüștür. Bu yöntem, kaliteyi ve verimliliği artırmıştır. İşlem yeteneği endeksleri (PCI'ler), bir işlemin tanımlanmıs yetenek önkoşulunu onaylayıp onaylamadı̆̆ına dair sayısal önlemler sağlar. Bunlar, sürecin şartname sınırlarını (SL'ler) ne kadar iyi karşıladığına karar verme yeteneğini ölçmek için kullanılmıştır. PCI'lar şirketler tarafindan kalite ve verimlilik performansını değerlendirmek için uygulanmıştır. X-R kontrol grafikleri kullanılarak yapılan bulanık proses yeterlilik analizi daha doğru sonuçlar vermiştir.

Anahtar Kelimeler: İstatistiksel Proses Kontrolü, Bulanık Kontrol Kartı, Proses Yeterlilik İndeksleri, Alüminyum

Cite

Arslan, V., (2020). "A fuzzy application of mean and range control charts of an aluminum production plant using fuzzy triangular numbers", Mugla Journal of Science and Technology, 6(2),43-51.

\section{Introduction}

The control chart originated in the early 1920s, it has become a powerful tool in statistical process control (SPC) that is the most widely used in industrial processes. Control charts are designed to monitor the process of change in mean and variance; they also reflect the ability of the process. Control charts have two types: variable and attribute. Control chart technique is well-known as a key step in production process monitoring. The control chart has a major function in detecting the occurrence of assignable causes, so that the necessary correction can be made before nonconforming products are manufactured in a large amount. The control chart technique may be considered as both the graphical expression and operation of statistical hypothesis testing. It is recommended that if a control chart is employed to monitor process, some test parameters should be determined such as the sample size, the sampling interval between successive samples, and the control limits or critical regions of the chart. SPC is an efficient technique for improvement of a firm's quality and productivity. The main objective of SPC is similar to that of the control chart technique, that is, to rapidly examine the occurrence of assignable causes or process shifts [1].

The fuzzy set theory is a more suitable tool for handling attribute data since these data may be expressed in linguistic terms such as "very good", "good", "medium", 
"bad", and "very bad". The first application of fuzzy set theory in the area of SPC goes back to Bradshaw who used fuzzy sets as a basis for the explanation of the measurement of the conformity of each product units with the specifications [2]. Since then, several researchers [3-7] attempt to use fuzzy set theory in the area of SPC and control charts. These researchers have used the fuzzy set theory for the construction of fuzzy control charts. Since fuzzy data ubiquitously exist in the modern manufacturing process, for monitoring its sample average and variance, it offered the fuzzy $\mathrm{X}$ and $\mathrm{R}$ control charts, whose fuzzy control limits are obtained on the basis of the results of the resolution identity, a well-known theory in the fuzzy set field. By using the fuzzy dominance approach, which compares the fuzzy averages and variances to their respective fuzzy control limits, they are capable of determining whether the manufacturing process is needed to be adjusted or not [7-12]. Additionally, some researchers studied "fuzzy rule based method" to construct their fuzzy control charts. [13] proposed firstly the fuzzy rule method for evaluating the fuzzy control charts in their paper. Their method is based on some rules which define all possible patterns of a process. Also, they applied the suggested method for fuzzy X-R control charts by using a symmetric triangular fuzzy number. [14] applied fuzzy statistical quality control to a calcite grinding plant in Niğde. The data, used to in this study, were obtained from Eti Aluminum Company in Konya-Turkey (Fig. 1).

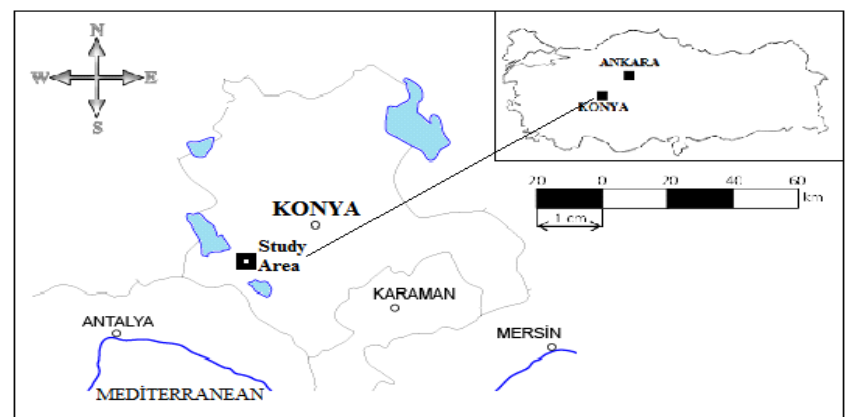

Figure 1. Location of studied area at Seydişehir/Turkey.

In this study, an application was presented for fuzzy method mean and range control charts. Fuzzy control charts were drawn using Eti Aluminum plant feeding material and concentrate data, and whether the process was in-control was analyzed. In addition, test samples were also made to chemically analysis with X-ray diffraction (XRD). This paper is organized as follows: In Section 2, general information about aluminum plant and chemical analysis of feeding material and concentrate were given. In addition, equations where the parameters used in drawing the X-R control charts were calculated. Finally, the main principles of fuzzy method control charts were explained. In Section 3, tables and graphics created with the data obtained from the plant were given. Finally, in Section 4, evaluation of the results and suggestions of solution presented to Eti Aluminum Company were given.

\section{Materials and Methods}

Eti Aluminum Company was established in 1973. It put into operation for production of alumina, raw aluminum and bulk products in 1973. Eti Aluminum was acquired by Cengiz Holding in 2005 in scope of privatization. Eti Aluminum, which is Turkey's biggest aluminum producer, is also one of the world's most important integrated plants capable of performing production from mine extraction until concentrate. The flowsheet of bayer process used in aluminum production is given in Fig. 2.

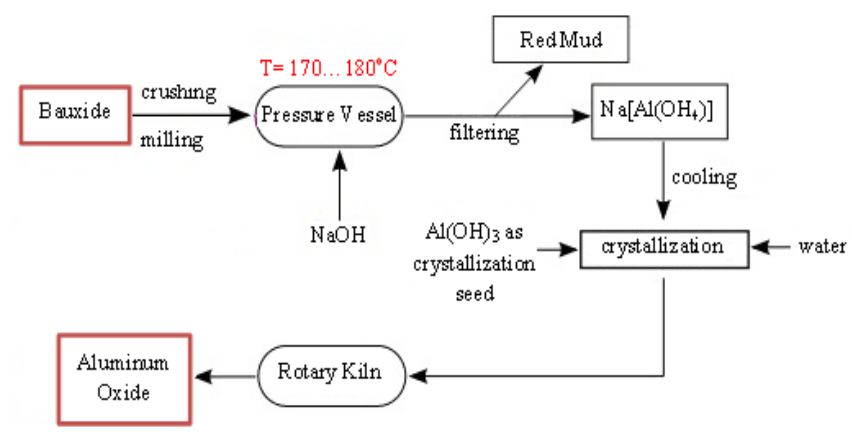

Figure 2. The flowsheet of bayer process used in Eti Aluminum Co.

The chemical analysis of the feeding material and concentrate were performed using lithium tetra borate fusion method ( $\mathrm{HCl}$ digestion) and an atomic absorption spectrophotometer (AAS) analysis. Chemical composition of the samples was presented in Table 1.

Table 1 . The results of chemical analysis of the samples.

\begin{tabular}{ccc}
\hline Sample & $\begin{array}{c}\text { Feeding Material } \\
(\%)\end{array}$ & $\begin{array}{c}\text { Concentrate (Dry } \\
\text { Hydrate) (\%) }\end{array}$ \\
\hline $\mathrm{Al}(\mathrm{OH})_{3}$ & - & 99.84 \\
$\mathrm{Al}_{2} \mathrm{O}_{3}$ & 59.09 & 65.28 \\
$\mathrm{Fe}_{2} \mathrm{O}_{3}$ & 17.16 & 0.007 \\
$\mathrm{SiO}_{2}$ & 7.41 & 0.006 \\
$\mathrm{TiO}_{2}$ & 2.67 & 0.001 \\
$\mathrm{CaO}$ & 0.73 & 0.006 \\
$\mathrm{Na}_{2} \mathrm{O}$ & 0.52 & 0.131 \\
$\mathrm{Moisture}$ & 3.57 & 2.28 \\
\hline
\end{tabular}

\subsection{Shewhart mean and range control charts}

If process output can be measured with a numerical expression, control cards can be mentioned for the variables. The most commonly used control cards are the X-R control cards. These cards are used for variables whose process characteristics can be expressed numerically. In the mining industry, quality data are usually measurable and therefore X-R control cards are more suitable to use. While drawing the control cards, the data is marked according to the rational sampling. In this sampling, subgroups with a certain number $(\mathrm{m})$ and size (n) are created. Subgroup samples can be sampled 
from the process at a specific time in a given time period or at different moments of the time period. The most important parameters that must be calculated in order to draw a control chart are the lower control limit (LCL) and the upper control limit (UCL). These limits refer to \pm 3a distance from the center line showing the overall average of the subgroups, or $99.73 \%$ area of the standard normal distribution curve. As a result, these are calculated according to the following Equations (1-6).

$$
\begin{aligned}
& \overline{\bar{X}}=\frac{\bar{X}_{a}+\bar{X}_{b}+\bar{X}_{c}+\cdots+\bar{X}_{m}}{m} \\
& \mathrm{UCL}_{X}=\overline{\bar{X}}+\frac{3}{d_{2} \sqrt{n}} \bar{R}=\overline{\bar{X}}+A_{2} \bar{R} \\
& \mathrm{LCL}_{X}=\overline{\bar{X}}-\frac{3}{d_{2} \sqrt{n}} \bar{R}=\overline{\bar{X}}-A_{2} \bar{R} \\
& \bar{R}=\frac{R_{a}+R_{b}+R_{c}+\cdots+R_{m}}{m} \\
& \mathrm{UCL}_{R}=\bar{R}+3 d_{3} \frac{\bar{R}}{d_{2}}=D_{4} \bar{R} \\
& L_{C L}=\bar{R}-3 d_{3} \frac{\bar{R}}{d_{2}}=D_{3} \bar{R}
\end{aligned}
$$

In the equations above; $A_{2}, D_{3}$ and $D_{4}$ are the constant values. In calculating the lower and upper control limits, suitable ones from these constant values in Table 2 are used [15-18].

Table 2. Constants for control charts [17].

\begin{tabular}{ccccc}
\hline $\begin{array}{c}\text { Subgroup } \\
\text { Size (n) }\end{array}$ & $\mathrm{A}_{2}$ & $\mathrm{~d}_{2}$ & $\mathrm{D}_{3}$ & $\mathrm{D}_{4}$ \\
\hline 2 & 1.880 & 1.128 & 0.000 & 3.267 \\
3 & 1.023 & 1.693 & 0.000 & 2.574 \\
4 & 0.729 & 2.059 & 0.000 & 2.282 \\
5 & 0.577 & 2.326 & 0.000 & 2.114 \\
6 & 0.483 & 2.534 & 0.000 & 2.004 \\
7 & 0.419 & 2.704 & 0.076 & 1.924 \\
\hline
\end{tabular}

\subsection{Fuzzy $X$ and $R$ control charts for triangular fuzzy numbers}

Suppose a quality feature is defined as "approximately $\mathrm{X}^{\prime \prime}$. According to fuzzy sets, this value is converted to triangle fuzzy number $(\mathrm{TFN})=\left(\mathrm{X}_{\mathrm{a}}, \mathrm{X}_{\mathrm{b}}, \mathrm{X}_{\mathrm{c}}\right)$. In this study, each observation is considered as a triangular fuzzy number $\tilde{X}_{i j}=\left(X_{a_{i j}}, X_{b_{i j}}, X_{c_{i j}}\right) ; i=1,2, ., m ; j=1,2, ., n$ where $m$ is the number of subgroup and $n$ is the sample size in each subgroup. If $\left(X_{a_{i 1}}, X_{b_{i 1}}, X_{c_{i 1}}\right), \ldots,\left(X_{a_{i n}}, X_{b_{i n}}, X_{c_{i n}}\right)$ is a sample of $n$ fuzzy observations in subgroup $i$, then $\left(\bar{X}_{a_{i}}, \bar{X}_{b_{i}}, \bar{X}_{c_{i}}\right)$, the average of each sample and the range of the subgroup $i$ is

$$
\begin{aligned}
& \overline{\mathrm{X}}_{a, b, \mathrm{c}_{\mathrm{i}}}=\frac{\sum_{\mathrm{j}=1}^{\mathrm{n}} \mathrm{X}_{a, b, \mathrm{c}_{\mathrm{ij}}}}{\mathrm{n}} \\
& \mathrm{R}_{\mathrm{a}_{\mathrm{i}}}=\left(\max _{\mathrm{a}_{\mathrm{ij}}}\right)-\left(\operatorname{minX}_{\mathrm{c}_{\mathrm{ij}}}\right) ;
\end{aligned}
$$

$$
\begin{aligned}
& \mathrm{R}_{\mathrm{b}_{\mathrm{i}}}=\left(\max \mathrm{X}_{\mathrm{b}_{\mathrm{ij}}}\right)-\left(\min _{\mathrm{b}_{\mathrm{ij}}}\right) ; \\
& \mathrm{R}_{\mathrm{c}_{\mathrm{i}}}=\left(\max \mathrm{X}_{\mathrm{c}_{\mathrm{ij}}}\right)-\left(\min \mathrm{X}_{\mathrm{a}_{\mathrm{ij}}}\right)
\end{aligned}
$$

To draw the fuzzy $X$ control chart, firstly; $\widetilde{C L}_{\bar{X}}=$ $\left(\widetilde{\mathrm{CL}}_{\mathrm{a}}, \widetilde{\mathrm{CL}}_{\mathrm{b}}, \widetilde{\mathrm{CL}}_{\mathrm{c}}\right)$ must be calculated. $\widetilde{\mathrm{CL}}_{\overline{\mathrm{X}}}$, calculated according to Equation 9, is the fuzzy arithmetic mean of the observations. For calculating UCLx, LCLx, UCL $L_{R}$ and ${ }_{L C L}$, control limits of fuzzy mean and range graphics can be obtained using Equations (10-13) [17,19,20].

$$
\begin{aligned}
& \widetilde{\mathrm{CL}}_{\overline{\mathrm{X}}}=\left(\overline{\overline{\mathrm{X}}}_{\mathrm{a}}, \overline{\overline{\mathrm{X}}}_{\mathrm{b}}, \overline{\overline{\mathrm{X}}}_{\mathrm{c}}\right) ; \quad \overline{\overline{\mathrm{X}}}_{\mathrm{k}}=\frac{\sum_{\mathrm{i}=1}^{\mathrm{m}} \overline{\mathrm{X}}_{\mathrm{k}_{\mathrm{i}}}}{\mathrm{m}} ; \\
& \overline{\mathrm{R}}_{\mathrm{k}}=\frac{\sum_{\mathrm{i}=1}^{\mathrm{m}} \mathrm{R}_{\mathrm{k}_{\mathrm{i}}}}{\mathrm{m}} \\
& \widetilde{\mathrm{UC} L_{\overline{\mathrm{X}}}}=\widetilde{\mathrm{CL}}_{\overline{\mathrm{X}}}+\mathrm{A}_{2} \overline{\mathrm{R}}=\left(\overline{\overline{\mathrm{X}}}_{\mathrm{a}, \mathrm{b}, \mathrm{c}}+\mathrm{A}_{2} \overline{\mathrm{R}}_{\mathrm{a}, \mathrm{b}, \mathrm{c}}\right) \\
& \widetilde{\mathrm{CC}} \overline{\mathrm{X}}_{\overline{\mathrm{X}}}=\widetilde{\mathrm{CL}}_{\overline{\mathrm{X}}}-\mathrm{A}_{2} \overline{\mathrm{R}}=\left(\overline{\overline{\mathrm{X}}}_{\mathrm{a}, \mathrm{b}, \mathrm{c}}-\mathrm{A}_{2} \overline{\mathrm{R}}_{\mathrm{a}, \mathrm{b}, \mathrm{c}}\right) \\
& \widetilde{\mathrm{UC}} \mathrm{L}_{\mathrm{R}}=\mathrm{D}_{4} \widetilde{\overline{\mathrm{R}}}=\left(\mathrm{D}_{4} \overline{\mathrm{R}}_{\mathrm{a}} ; \mathrm{D}_{4} \overline{\mathrm{R}}_{\mathrm{b}} ; \mathrm{D}_{4} \overline{\mathrm{R}}_{\mathrm{c}}\right) \\
& \widetilde{\mathrm{LC}} \mathrm{L}_{\mathrm{R}}=\mathrm{D}_{3} \widetilde{\overline{\mathrm{R}}}=\left(\mathrm{D}_{3} \overline{\mathrm{R}}_{\mathrm{a}} ; \mathrm{D}_{3} \overline{\mathrm{R}}_{\mathrm{b}} ; \mathrm{D}_{3} \overline{\mathrm{R}}_{\mathrm{c}}\right)
\end{aligned}
$$

\subsection{Fuzzy process capability indices}

Process capability indices (PCIs) are used to determine whether the products can be produced within the quality standards required by the customer. If the process meets the demands of the customer, this process is called "capable". We determine how well a process fulfills the requests by process capability indices. The two most common PCI standards are $\mathrm{C}_{\mathrm{p}}$ and $C_{p k}$ [16]. The $C_{p}$ index, which is the most used index in the literature, is the ratio of specification limits (USLLSL) to process spread $(6 \sigma)$. The specification limits are the customer's demands. The larger the process variation, the smaller the $C_{p}$ value. $C_{p}$ is an indication of how much the process remains within the upper and lower specification limits. Process capability ratio $C_{p}$ does not take into account some data in the process, so it usually does not reflect actual process performance. [21] developed the $\mathrm{C}_{\mathrm{pk}}$ index to overcome problems caused by $\mathrm{C}_{\mathrm{p}}$. It shows how a process verifies its limits. The index is often used to associate "natural tolerances $(3 \sigma)$ " with the specification limits. $C_{\mathrm{pk}}$ shows how much the process is within specification limits according to the process average. $C_{\mathrm{pk}}$ shows how much the process is within the specification limits according to the process average. $C_{p}, C_{p u}, C_{p l}$ and $C_{p k}$ are calculated according to 14-15 Equations.

$$
\begin{aligned}
& C_{p}=\frac{U S L-L S L}{6 \sigma} ; C_{p k}=\min \left\{C_{p u}, C_{p l}\right\} \\
& C_{p u}=\frac{U S L-\mu}{3 \sigma} ; \quad C_{p l}=\frac{\mu-L S L}{3 \sigma}
\end{aligned}
$$

where $\mu$ used in the calculation of $\mathrm{Cpu}$ and $\mathrm{Cpl}$ indicates the average process. The calculated $\mathrm{Cp}$ value gives us an idea of process efficiency. The relationship between quality conditions and $\mathrm{Cp}$ values is given in Table 3 $[13,22,23]$. When referring to specification limits (SLs), expressions such as "about" and "around" are preferred. Triangular fuzzy numbers (TFN) are used to convert this variable to fuzzy numbers. In addition, fuzzy process mean and standard deviation are calculated 
according to Equation 16. Fuzzy process capability indices are calculated as follows Equations 17-19.

$$
\begin{aligned}
& \tilde{\mu}=\overline{\bar{X}}=\operatorname{TFN}\left(\mu_{1,2,3}\right) ; \widetilde{\sigma}=\frac{\overline{\mathrm{R}}}{\mathrm{d}_{2}}=\operatorname{TFN}\left(\sigma_{1,2,3}\right) \\
& \tilde{\mathrm{C}}_{\mathrm{p}}=\frac{\widetilde{\mathrm{USL}}-\widetilde{\mathrm{SSL}}}{6 \widetilde{\sigma}}=\operatorname{TFN}\left(\frac{\mathrm{u}_{1,2,3}-\mathrm{l}_{1,2,3}}{6 \sigma_{1,2,3}}\right) \\
& \tilde{\mathrm{C}}_{\mathrm{pu}}=\frac{\widetilde{\mathrm{USL}}-\tilde{\mu}}{3 \widetilde{\sigma}}=\operatorname{TFN}\left(\frac{\mathrm{u}_{1,2,3}-\mu_{1,2,3}}{3 \sigma_{1,2,3}}\right) \\
& \tilde{\mathrm{C}}_{\mathrm{pl}}=\frac{\tilde{\mu}-\widetilde{\mathrm{LSL}}}{3 \widetilde{\sigma}}=\operatorname{TFN}\left(\frac{\mu_{1,2,3}-\mathrm{l}_{1,2,3}}{3 \sigma_{1,2,3}}\right)
\end{aligned}
$$

Table 3. Quality status and $\mathrm{C}_{\mathrm{p}}$ values [22].

\begin{tabular}{cc}
\hline Quality Status & $\mathrm{C}_{\mathrm{p}}$ Range \\
\hline Super excellent & $\mathrm{C}_{\mathrm{p}} \geq 2.00$ \\
Excellent & $1.67 \leq \mathrm{C}_{\mathrm{p}}<2.00$ \\
Satisfactory & $1.33 \leq \mathrm{C}_{\mathrm{p}}<1.67$ \\
Capable & $1.00 \leq \mathrm{C}_{\mathrm{p}}<1.33$ \\
Inadequate & $0.67 \leq \mathrm{C}_{\mathrm{p}}<1.00$ \\
Poor & $\mathrm{C}_{\mathrm{p}}<0.67$
\end{tabular}

The percentage of fuzzy observation area (PA) is one of the important parameters to determine whether the process is whether the process is under control. According to this, if $\mathrm{Xi}$ is between the fuzzy upper and lower control limits, PA equals zero and the process is in-control (Fig. 3a). If Xi is outside the fuzzy upper or lower control limits, $\mathrm{PA}$ is equal to 1 and the process is out-of-control (Fig. 3b). Finally, if Xi intersects with fuzzy upper or lower control limits, PA is between 0 and 1. In this case, the process is very close to the limit values and must be monitored continuously (Fig. 3c) [20].

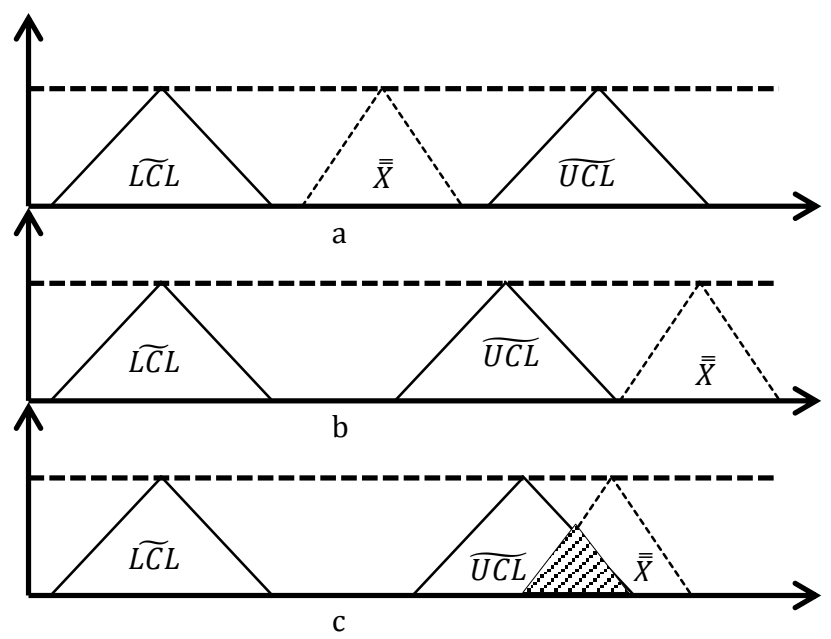

Figure 3. Process condition when the sample points and control limits are triangular fuzzy numbers a: in-control, b: out-of-control, c: rather-in-control or rather-out-ofcontrol.

\section{Results}

Moisture, $\mathrm{Fe}_{2} \mathrm{O}_{3}$ and $\mathrm{SiO}_{2}$ are among the most important parameters in aluminum production. For this reason, Eti Aluminum Company regularly monitors and controls the changes in these values. The company uses traditional Shewhart control charts at the stage of data control. In this study, fuzzy mean and range control charts were used to monitors the changes in the data of Eti Aluminum Co. Nowadays, this method has been widely used in many industrial areas (textile factories, machinery factories, ore dressing plants, etc.). 21-days data were collected to track the changes in the raw material delivered to the aluminum production facility in moisture, iron-oxide and quartz. The analyzed data were given in Figs. 4-6 ( $M=21$ (number of samples) and $\mathrm{n}=4$ (sample size)).

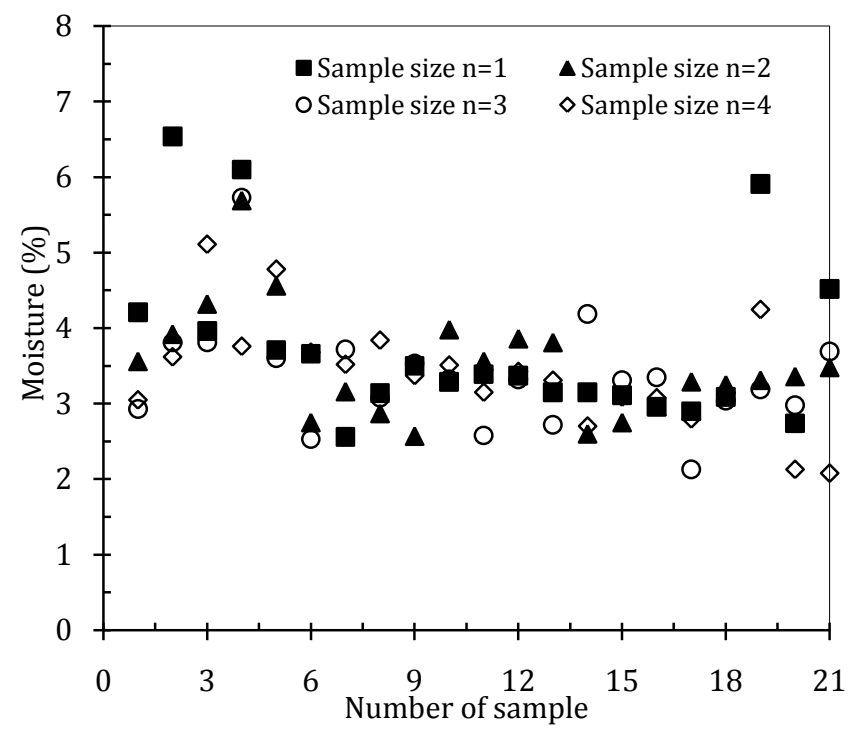

Figure 4. Case study data for moisture values.

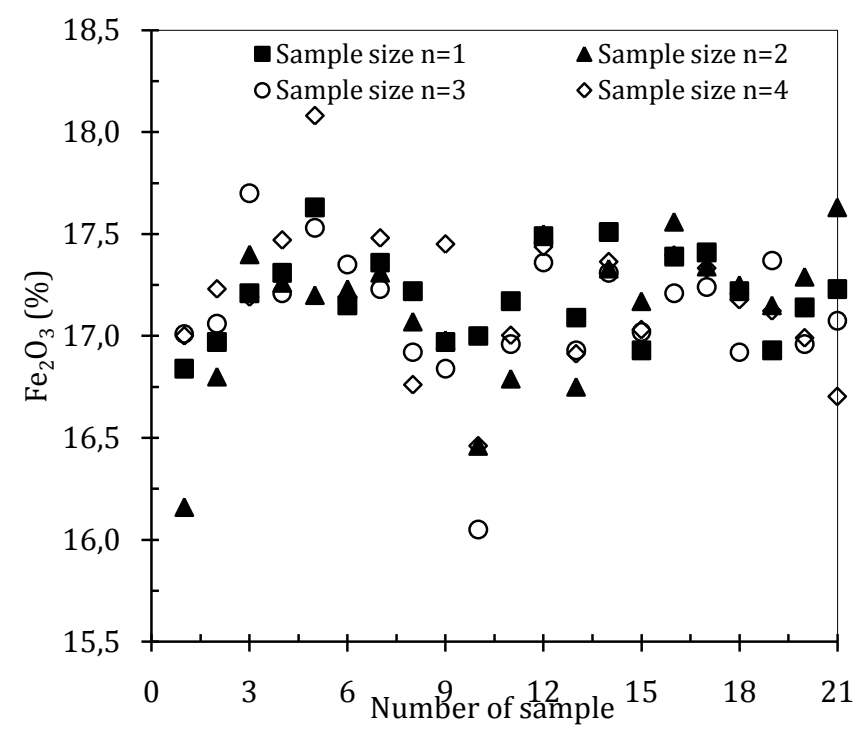

Figure 5. Case study data for $\mathrm{Fe}_{2} \mathrm{O}_{3}$ values. 


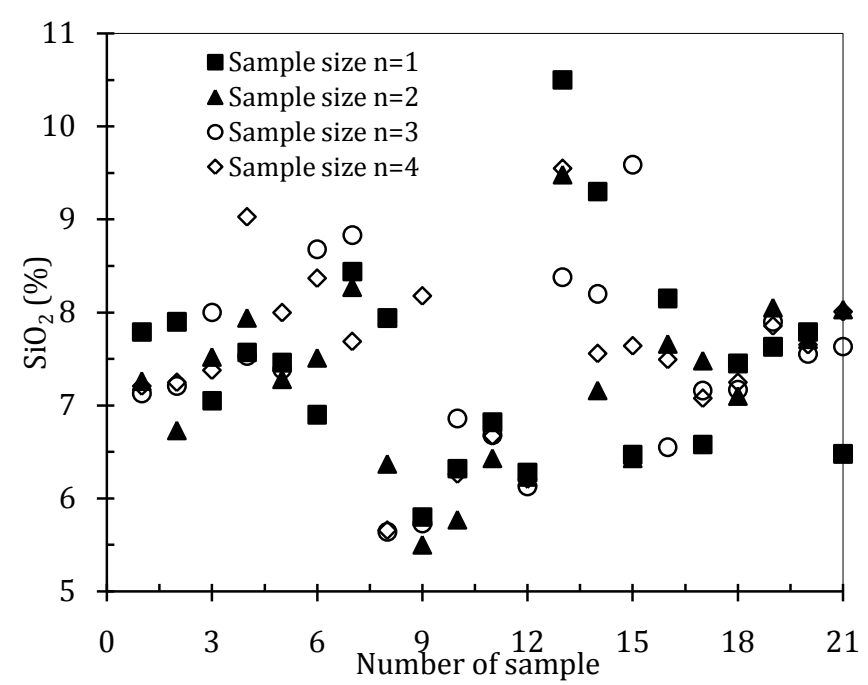

Figure 6. Case study data for $\mathrm{SiO}_{2}$ values.

In this section, an example is given using the data from the aluminum production plant to prove that the fuzzy mean and range control charts give more accurate and illuminating results. The application was made on controlling feeding material and concentrate (dry hydrate) values in aluminum production plant. Thirty samples with sample sizes of four (total number of measurements $4 \times 30=120$ ) have been taken from the putative points that the process is in-control according to the quality control techniques applied by the factory.

Due to environmental conditions, each measurement item is expressed as a triangular fuzzy number $(\mathrm{Xa}, \mathrm{Xb}$, $\mathrm{Xc}$ ). Tables 4 and 5 show the fuzzy triangular observations for feeding material and concentrate. Tables 6 and 7 show the result of each subgroup fuzzy mean and range calculation based on Equations 7-8 for feeding material and concentrate. Tables 6 and 7 also show the overall percentage of area (PA) of each observation remains outside the fuzzy control limits. When Tables 6 and 7 are examined carefully, it is seen that the vast majority of the analyzed data are incontrol. However, some data is out-of-control (data which PA is greater than zero). These data should be regularly monitored and the necessary improvement works should be taken into effect immediately. Using equations 9-13, Fuzzy triangular control limits $\left(\overline{U C L}_{\bar{X}}, \widetilde{C L_{\bar{X}}}, \widetilde{L C} L_{\bar{X}}, \widetilde{U C L}_{R}, \widetilde{C L}_{R}\right.$ and $\left.\widetilde{L C} L_{R}\right)$ are calculated as Table 8.

Table 4. Fuzzy triangular observations for feeding material.

\begin{tabular}{ccccccccccccc}
\hline & $\mathrm{X}_{\mathrm{a}_{1}}$ & $\mathrm{X}_{\mathrm{b}_{1}}$ & $\mathrm{X}_{\mathrm{c}_{1}}$ & $\mathrm{X}_{\mathrm{a}_{2}}$ & $\mathrm{X}_{\mathrm{b}_{2}}$ & $\mathrm{X}_{\mathrm{c}_{2}}$ & $\mathrm{X}_{\mathrm{a}_{3}}$ & $\mathrm{X}_{\mathrm{b}_{3}}$ & $\mathrm{X}_{\mathrm{c}_{3}}$ & $\mathrm{X}_{\mathrm{a}_{4}}$ & $\mathrm{X}_{\mathrm{b}_{4}}$ & $\mathrm{X}_{\mathrm{c}_{4}}$ \\
\hline 1 & 57.425 & 57.430 & 57.435 & 56.165 & 56.170 & 56.175 & 59.325 & 59.330 & 59.335 & 59.235 & 59.240 & 59.245 \\
2 & 57.555 & 57.560 & 57.565 & 59.585 & 59.590 & 59.595 & 58.725 & 58.730 & 58.735 & 59.335 & 59.340 & 59.345 \\
3 & 59.165 & 59.170 & 59.175 & 58.925 & 58.930 & 58.935 & 58.415 & 58.420 & 58.425 & 58.715 & 58.720 & 58.725 \\
4 & 58.785 & 58.790 & 58.795 & 58.105 & 58.110 & 58.115 & 58.975 & 58.980 & 58.985 & 56.955 & 56.960 & 56.965 \\
5 & 59.035 & 59.040 & 59.045 & 58.395 & 58.400 & 58.405 & 59.155 & 59.160 & 59.165 & 58.215 & 58.220 & 58.225 \\
. &. &. &. &. &. &. &. &. &. &. &. &. \\
. &. &. &. &. &. &. &. &. &. &. &. &. \\
29 & 58.785 & 58.790 & 58.795 & 60.175 & 60.180 & 60.185 & 58.835 & 58.840 & 58.845 & 55.585 & 55.590 & 55.595 \\
30 & 58.615 & 58.620 & 58.625 & 59.595 & 59.600 & 59.605 & 56.535 & 56.540 & 56.545 & 58.735 & 58.740 & 58.745 \\
\hline
\end{tabular}

Table 5. Fuzzy triangular observations for concentrate (dry hydrate).

\begin{tabular}{ccccccccccccc}
\hline & $\mathrm{X}_{\mathrm{a}_{1}}$ & $\mathrm{X}_{\mathrm{b}_{1}}$ & $\mathrm{X}_{\mathrm{c}_{1}}$ & $\mathrm{X}_{\mathrm{a}_{2}}$ & $\mathrm{X}_{\mathrm{b}_{2}}$ & $\mathrm{X}_{\mathrm{c}_{2}}$ & $\mathrm{X}_{\mathrm{a}_{3}}$ & $\mathrm{X}_{\mathrm{b}_{3}}$ & $\mathrm{X}_{\mathrm{c}_{3}}$ & $\mathrm{X}_{\mathrm{a}_{4}}$ & $\mathrm{X}_{\mathrm{b}_{4}}$ & $\mathrm{X}_{\mathrm{c}_{4}}$ \\
\hline 1 & 99.849 & 99.854 & 99.859 & 99.847 & 99.852 & 99.857 & 99.842 & 99.847 & 99.852 & 99.855 & 99.860 & 99.865 \\
2 & 99.849 & 99.854 & 99.859 & 99.858 & 99.863 & 99.868 & 99.836 & 99.841 & 99.846 & 99.835 & 99.840 & 99.845 \\
3 & 99.840 & 99.845 & 99.850 & 99.860 & 99.865 & 99.870 & 99.851 & 99.856 & 99.861 & 99.847 & 99.852 & 99.857 \\
4 & 99.840 & 99.845 & 99.850 & 99.858 & 99.863 & 99.868 & 99.835 & 99.840 & 99.845 & 99.835 & 99.840 & 99.845 \\
5 & 99.826 & 99.831 & 99.836 & 99.847 & 99.852 & 99.857 & 99.852 & 99.857 & 99.862 & 99.835 & 99.840 & 99.845 \\
. &. &. &. &. &. &. &. &. &. &. &. &. \\
. &. &. &. &. &. &. &. &. &. &. &. &. \\
29 & 99.794 & 99.799 & 99.804 & 99.820 & 99.825 & 99.830 & 99.802 & 99.807 & 99.812 & 99.813 & 99.818 & 99.823 \\
30 & 99.821 & 99.826 & 99.831 & 99.816 & 99.821 & 99.826 & 99.826 & 99.831 & 99.836 & 99.748 & 99.753 & 99.758 \\
\hline
\end{tabular}


Table 6. Fuzzy mean, range and PA for feeding material.

\begin{tabular}{|c|c|c|c|c|c|c|c|}
\hline Subgroup & $\overline{\mathrm{X}}_{\mathrm{a}}$ & $\overline{\mathrm{X}}_{\mathrm{b}}$ & $\overline{\mathrm{X}}_{\mathrm{c}}$ & $P A_{\bar{X}}$ & $\mathrm{R}_{\mathrm{a}}$ & $\mathrm{R}_{\mathrm{b}}$ & $\mathrm{R}_{\mathrm{c}}$ \\
\hline 1 & 58.038 & 58.043 & 58.048 & 0 & 3.15 & 3.16 & 3.17 \\
\hline 2 & 58.800 & 58.805 & 58.810 & 0 & 2.02 & 2.03 & 2.04 \\
\hline 3 & 58.805 & 58.810 & 58.815 & 0 & 0.74 & 0.75 & 0.76 \\
\hline 4 & 58.205 & 58.210 & 58.215 & 0 & 2.01 & 2.02 & 2.03 \\
\hline 5 & 58.700 & 58.705 & 58.710 & 0 & 0.93 & 0.94 & 0.95 \\
\hline 6 & 59.193 & 59.198 & 59.203 & 0 & 2.15 & 2.16 & 2.17 \\
\hline 7 & 58.480 & 58.485 & 58.490 & 0 & 1.20 & 1.21 & 1.22 \\
\hline 8 & 60.678 & 60.683 & 60.688 & 0.158 & 2.67 & 2.68 & 2.69 \\
\hline 9 & 60.863 & 60.868 & 60.873 & 0.389 & 3.21 & 3.22 & 3.23 \\
\hline 10 & 59.436 & 59.441 & 59.446 & 0 & 3.43 & 3.44 & 3.45 \\
\hline 11 & 59.705 & 59.710 & 59.715 & 0 & 1.23 & 1.24 & 1.25 \\
\hline 12 & 60.284 & 60.289 & 60.294 & 0 & 0.44 & 0.45 & 0.46 \\
\hline 13 & 57.259 & 57.264 & 57.269 & 0.225 & 2.06 & 2.07 & 2.08 \\
\hline . & . & . & . & . & . & . & . \\
\hline . & . & . & . & . & . & . & . \\
\hline 30 & 58.370 & 58.375 & 58.380 & 0 & 3.05 & 3.06 & 3.07 \\
\hline Average & 58.998 & 59.003 & 59.008 & & 1.84 & 1.85 & 1.86 \\
\hline \multicolumn{8}{|c|}{ Table 7. Fuzzy mean, fuzzy range and PA for concentrate. } \\
\hline Subgroup & $\overline{\mathrm{X}}_{\mathrm{a}}$ & $\overline{\mathrm{X}}_{\mathrm{b}}$ & $\overline{\mathrm{X}}_{\mathrm{c}}$ & $\mathrm{PA}_{\overline{\mathrm{X}}}$ & $\mathrm{R}_{\mathrm{a}}$ & $\mathrm{R}_{\mathrm{b}}$ & $\mathrm{R}_{\mathrm{c}}$ \\
\hline 1 & 99.848 & 99.853 & 99.858 & 0 & 0.01 & 0.01 & 0.02 \\
\hline 2 & 99.845 & 99.850 & 99.855 & 0 & 0.01 & 0.02 & 0.03 \\
\hline 3 & 99.850 & 99.855 & 99.860 & 0 & 0.01 & 0.02 & 0.03 \\
\hline 4 & 99.842 & 99.847 & 99.852 & 0 & 0.01 & 0.02 & 0.03 \\
\hline 5 & 99.840 & 99.845 & 99.850 & 0 & 0.02 & 0.03 & 0.04 \\
\hline 6 & 99.848 & 99.853 & 99.858 & 0 & 0.03 & 0.04 & 0.05 \\
\hline 7 & 99.850 & 99.855 & 99.860 & 0 & 0.01 & 0.02 & 0.03 \\
\hline 8 & 99.850 & 99.855 & 99.860 & 0 & 0.02 & 0.03 & 0.04 \\
\hline 9 & 99.848 & 99.853 & 99.858 & 0 & 0.03 & 0.04 & 0.05 \\
\hline 10 & 99.833 & 99.838 & 99.843 & 0 & 0.03 & 0.04 & 0.05 \\
\hline 11 & 99.819 & 99.824 & 99.829 & 0 & 0.03 & 0.04 & 0.05 \\
\hline 12 & 99.799 & 99.804 & 99.809 & 0.92 & 0.07 & 0.08 & 0.09 \\
\hline 13 & 99.829 & 99.834 & 99.839 & 0 & 0.04 & 0.05 & 0.06 \\
\hline . & . & . & . & . & . & . & $\cdot$ \\
\hline . & . & . & . & . & . & . & . \\
\hline 30 & 99.802 & 99.807 & 99.812 & 0.47 & 0.07 & 0.08 & 0.09 \\
\hline Average & 99.833 & 99.838 & 99.843 & & 0.03 & 0.04 & 0.05 \\
\hline
\end{tabular}


Table 8. Fuzzy triangular control limits.

\begin{tabular}{ccccccc}
\hline & \multicolumn{3}{c}{ Feeding Material } & \multicolumn{3}{c}{ Concentrate } \\
\hline$\widetilde{\mathrm{UCL}}_{\overline{\mathrm{x}}}$ & 60.342 & 60.354 & 60.367 & 99.853 & 99.866 & 99.878 \\
$\widetilde{\mathrm{CL}}$ & 59.081 & 59.086 & 59.092 & 99.833 & 99.838 & 99.843 \\
$\widetilde{\mathrm{LCL}}$ & 57.653 & 57.651 & 57.649 & 99.813 & 99.811 & 99.809 \\
$\widetilde{\mathrm{UCL}}$ & 4.209 & 4.231 & 4.254 & 0.063 & 0.086 & 0.109 \\
$\widetilde{\mathrm{CL}}_{\mathrm{R}}$ & 1.844 & 1.854 & 1.864 & 0.028 & 0.038 & 0.048 \\
$\widetilde{\mathrm{LCL}}_{\mathrm{R}}$ & 0 & 0 & 0 & 0 & 0 & 0
\end{tabular}

When the PA values are examined in Tables 6 and 7, it is seen that the system is out-of-control for the data where the PA values are greater than zero (samples 8, 9 and 13 for feeding material, samples 18 and 30 for concentrate). This situation should be urgently analyzed and studies should be started to improve the process. To compare X-R control charts used to monitor quality parameters by the company and the fuzzy mean and range control charts proposed by me, the mean value of the fuzzy observations is calculated according to the Equation 20 as the crisp value to construct the $\mathrm{X}-\mathrm{R}$ control charts [20].

$$
E\left(\widetilde{X}_{i j}\right)=\frac{X_{a_{i j}}+2 X_{b_{i j}}+X_{c_{i j}}}{4}
$$

Researchers who want to learn more about the mean and expected value of fuzzy numbers can refer to [24]. Figs. 7 and 8 show Shewhart mean and range control charts for feeding material and concentrate data. The use of the recommended fuzzy control charts instead of the statistical process control method currently used in Eti Aluminum Plant shows that it helps improve the quality of aluminum and dry hydrate as well as increase production efficiency.

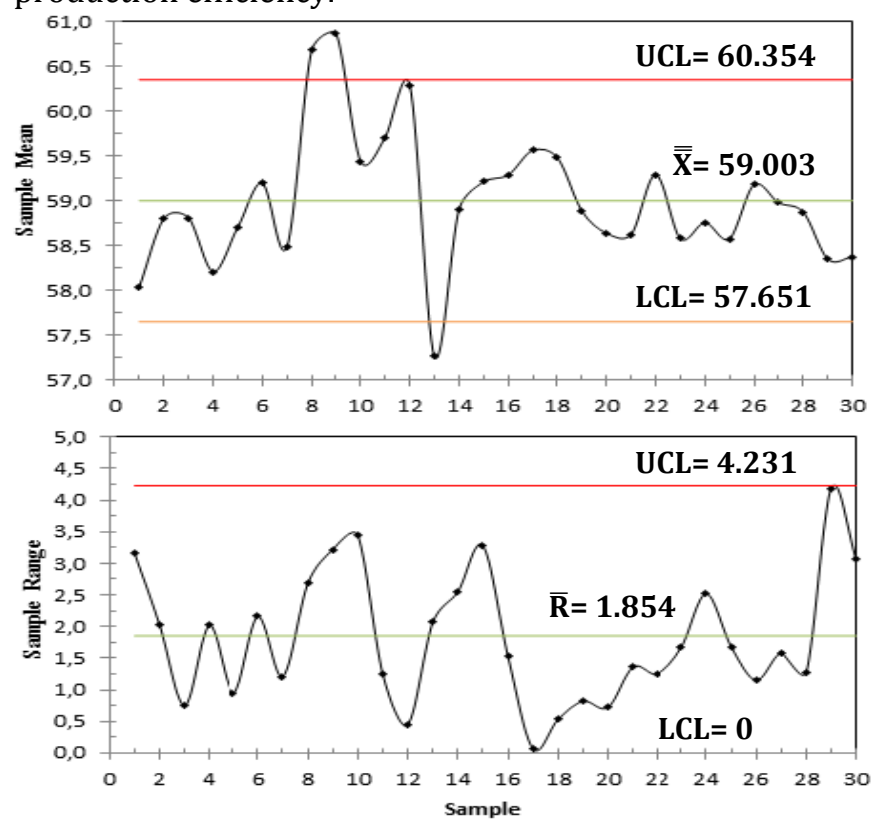

Figure 7. Mean and range charts for feeding material from aluminum production plant.
When Fig. 7, which is drawn using the feeding material data in the aluminum production plant, is examined, It is clearly seen that the samples 8,9 and 13 are outside the control limits. In addition to, sample 12 is very close to the upper control limit. In the light of these data, the feeding material line should be carefully reviewed and the conditions causing the above errors should be corrected. If these errors are not corrected, this will cause larger problems in the future.

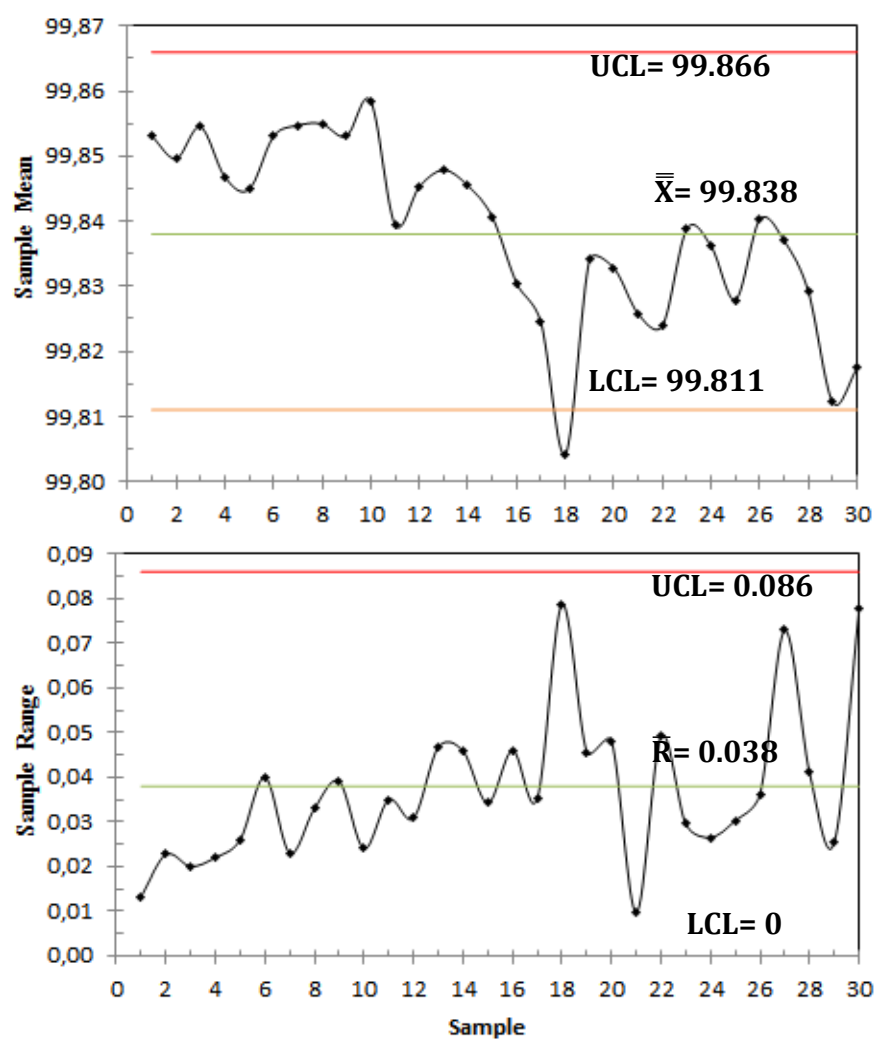

Figure 8. Mean and range charts for concentrate (dry hydrate) from aluminum production plant

When Fig. 8 is examined, analyses of the data from sample 18 for concentrate indicate that it is above the UCL and there are large fluctuations. The reason for this might be that the concentrate properties at the aluminum plant were not homogenous. Generally, it was not observed that there was a serious problem at this factory during the period of testing. However, the data in the concentrate line should be constantly monitored. 
TFNs of (USL) and (LSL) were obtained from the company's quality control department of Eti Aluminum Co. The $\tilde{\mu}, \widetilde{\sigma}, \widetilde{\mathrm{C}}_{\mathrm{p}}, \widetilde{\mathrm{C}}_{\mathrm{pu}}$ and $\tilde{\mathrm{C}}_{\mathrm{pl}}$ values were calculated using aluminum concentrate data. According to the data in Table 9, it is decided whether the process is in-control or out-of-control. The $\tilde{\mu}, \widetilde{\sigma}, \tilde{\mathrm{C}}_{\mathrm{p}}, \tilde{\mathrm{C}}_{\mathrm{pu}}$ and $\tilde{\mathrm{C}}_{\mathrm{pl}}$ were calculated using equation 17-20. These indices are calculated as $2.917,2.269,1.775 ; 3.738,2.907,2.275$ and $2.0951 .630,1.375$ respectively. While calculating these data, data collection was performed in three replications and calculated parameter values were greater than 1.33. As a result, the concentrated production efficiency and product quality of the aluminum production plant is adequate.

Table 9. Fuzzy capability indexes and values of $\tilde{\mu}, \widetilde{\sigma}, \tilde{C}_{p}$, $\tilde{\mathrm{C}}_{\mathrm{pu}}, \widetilde{\mathrm{C}}_{\mathrm{pl}}$ concentrate of aluminum plant.

\begin{tabular}{cccc}
\hline \multicolumn{4}{c}{ Concentrate (dry hydrate) } \\
\hline$\widetilde{\mathrm{US} L}$ & 99.990 & 99.995 & 100.00 \\
$\widetilde{\mathrm{SL}}$ & 99.745 & 99.750 & 99.755 \\
$\tilde{\mu}$ & 99.833 & 99.838 & 99.843 \\
$\widetilde{\sigma}$ & 0.014 & 0.018 & 0.023 \\
$\tilde{\mathrm{C}}_{\mathrm{p}}$ & 2.917 & 2.269 & 1.775 \\
$\tilde{\mathrm{C}}_{\mathrm{pu}}$ & 3.738 & 2.907 & 2.275 \\
$\tilde{\mathrm{C}}_{\mathrm{pl}}$ & 2.095 & 1.630 & 1.375 \\
\hline
\end{tabular}

4. Conclusion

A statistical process control study was carried out using the fuzzy process control technique of Eti Aluminum Company's feeding material and concentrate data and the quality grade of the plant was controlled. The results obtained from this study are summarized below;

With this study, it is shown that X-R control charts and fuzzy set theory can be used together. Primarily, fuzzy triangle numbers were calculated by using appropriate equations and then fuzzy mean and range control graphs were drawn with the help of calculated data. The number of errors data in the process is calculated using the amount of sample remaining above the UCL or below the LCL and the percentage of sample mean (PA). Fuzzy mean and range control cards have been proposed to Eti Aluminum Company instead of the traditional control cards that it currently uses. With the use of the proposed fuzzy control charts, it is predicted that the quality of aluminum and dry hydrate will increase and also help increase production efficiency.

Statistical process control charts of the feeding material and concentrate data were drawn using the process capability index. Mean and range control charts created with feeding material and concentrate (dry hydrate) were observed to be in-control. In addition, the calculated $\tilde{\mathrm{C}}_{\mathrm{p}}$ values such as $2.917,2.269$ and 1.775 are higher than 1.33. Meanwhile, $\tilde{\mathrm{C}}_{\mathrm{pu}}$ and $\tilde{\mathrm{C}}_{\mathrm{pl}}$ values (3.738,
$2.907,2.275 ; 2.095,1.630,1.375$ respectively) are higher than 1.33. According to these calculated data, it is clearly seen that the process is adequate. It has been determined that the mean and range control charts drawn using the feeding material and concentrate data are in-control.

When the results obtained from this study are investigated, it is clearly seen that the fuzzy statistical process control methods are very efficient in Eti Aluminum Company production line. Finally, company management was recommended to use the fuzzy statistical process control method instead of the Shewhart control charts currently use.

\section{Acknowledgment}

The author specially thanks Burak ÖZEN and the managements of Eti Aluminum Company in Seydişehir/Turkey for their help in providing the necessary data and author also gratitude General Directorate of Mineral Research and Exploration of Turkey for providing support.

\section{References}

[1] Intaramo, R. and Pongpullponsak, A., "Development of fuzzy extreme value theory control charts using $\alpha$-cuts for skewed", Applied Mathematical Sciences, 6, 5811-5834, 2012.

[2] Bradshaw, C.W., "A fuzzy set theoretic interpretation of economic control limits", European Journal of Operational Research, 13, 403-408, 1983.

[3] Gülbay, M. and Kahraman, C., "An alternative approach to fuzzy control charts: direct fuzzy approach", Information Sciences, 177, 1463-1480, 2007.

[4] Shu, M.H. and Wu, H.C., "Fuzzy X and R control charts: fuzzy dominance approach", Computers \& Industrial Engineering, 61, 676-685, 2011.

[5] Tannock, J.D.T., "A fuzzy control charting method for individuals", International Journal of Production Research, 41, 13-22, 2003.

[6] Alizadeh, H.M. and Ghomi, S.M.T.F., "Fuzzy development of mean and range control charts using statistical properties of different representative values", Journal of Intelligent and Fuzzy Systems, 22, 253-265, 2011.

[7] Khademi, M. and Amirzadeh, V., "Fuzzy rules for fuzzy X and R control charts", Iranian Journal of Fuzzy Systems, 11, 55-66, 2014.

[8] Gülbay, M., Kahraman, C. and Ruan, D., " $\alpha$-Cuts fuzzy control charts for linguistic data", International Journal of Intelligent Systems, 19, 1173-1196, 2004.

[9] Gülbay, M. and Kahraman, C., "Development of fuzzy process control charts and fuzzy unnatural pattern analyses", Computational Statistics \& Data Analysis, 51, 434-451, 2006.

[10] Kanagawa, A., Tamaki, F. and Ohta, H., "Control charts for process average and variability based on linguistic data", International Journal of Production Research, 31, 913-922, 1993.

[11] Şentürk, S., Erginel, N., Kaya, I. and Kahraman, C., "Design of fuzzy U control chart", Journal of Multiple Valued-Logic and Soft Computing, 5, 459-473, 2011.

[12] Şentürk, S., "Construction of fuzzy C control charts based on fuzzy rule method", Anadolu University Journal of 
Science and Technology A-Applied Sciences and Engineering, 18, 563-572, 2017.

[13] Kaya, I. and Kahraman, C., "Process capability analyses based on fuzzy measurements and fuzzy control charts", Expert Systems with Applications, 38, 3172-3184, 2011.

[14] Uçurum, M., "Fuzzy statistical process control of a calcite grinding plant using total color difference parameter $(\Delta \mathrm{E})$ ", IOSR Journal of Engineering, 7, 7-22, 2017.

[15] Emami, G., Laleh, K.F. and Radfar, F., "A fuzzy application of $\mathrm{X}$ and R control charts using fuzzy triangular numbers", $2^{\text {nd }}$ International Conference on Modern Research's in Management, Economics Accounting, Malaysia, 2016.

[16] Montgomery, D.C., Introduction to Statistical Quality Control, $5^{\text {th }}$ ed., John Wiley \& Sons, USA, 2005.

[17] Montgomery, D.C., Statistical Quality Control: A Modern Introduction, $6^{\text {th }}$ ed., John Wiley \& Sons, USA, 2009.

[18] Prajapati, D.R., "Implementation of SPC techniques in automotive industry: A case study", International Journal of Emerging Technology and Advanced Engineering, 2, 227-241, 2012.

[19] Erginel, N., "Fuzzy individual and moving range control charts with $\alpha$-cuts", Journal of Intelligent \& Fuzzy Systems, 19, 373-383, 2008.

[20] Zabihinpour, S.M., Ariffin, M.K.A., Tang, S.H. and Azfanizam, A.S., "Fuzzy based approach for monitoring the mean and range of the products quality", Journal of Applied Environmental \& Biological Sciences, 4, 1-7, 2014.

[21] Kane, V.E., "Process capability indices", Journal of Quality Technology, 18, 41-52, 1986.

[22] Kaya, I. and Kahraman, C., "Development of fuzzy process accuracy index for decision making problems", Information Sciences, 180, 861-872, 2010.

[23] Kotz, S. and Johnson, N., "Process capability indices-A review 1992-2000", Journal of Quality Technology, 34, 219, 2002.

[24] Carlsson, C. and Fullér, R., "On possibilistic mean value and variance of fuzzy numbers", Fuzzy Sets and Systems, 122, 315-326, 2001. 